\title{
The Democratic Entitlement and Pro-Democratic Interventions: Twenty Years After Haiti?*
}

\author{
El derecho a la democracia y las intervenciones \\ prodemocráticas: ¿veinte años después de Haití?
}

\section{Cécile Vandewoude**}

SUMARIO: I. Introduction. II. Has the Security Council authorized any sanctions under Chapter VII to restore democracy since the intervention in Haiti? III. Has had the theory of the democratic entitlement any other influence on the Security Council's work? IV. Conclusion.

* Artículo recibido el 14 de julio de 2011 y aprobado para publicación el 28 de septiembre de 2011.

** Is a LL.M. graduate from the Georgetown University Law Center (USA) holding a primary law degree from the University of Antwerp (Belgium) and a first LL.M. degree from the Free University of Brussels (Belgium). Upon completion of internships at the Permanent Representation of Belgium to the United Nations (New York, USA), Human Rights First (New York, USA) and the United Nations Office for the Coordination of Humanitarian Affairs (New York, USA) she joined the Office of the Legal Advisor to the Supreme Allied Commander (NATO/SHAPE, Belgium) where she worked as a consultant for three years. Currently, she is completing a Ph.D. on "The Nexus between Democracy and Human Rights in International Law" at Ghent University (Ghent, Belgium) 
RESUMEN: En este artículo se analiza si la actitud de la comunidad internacional hacia la promoción de la democracia se ha modificado desde la intervención militar en Haití, que tuvo lugar hace casi veinte años. El artículo concluye que la misma se ha modificado en parte. La comunidad internacional, actuando a través del Consejo de Seguridad, aún generalmente se opone a la idea de que la fuerza militar pueda ser legítimamente utilizada para "restaurar" la democracia, sin embargo deja la puerta abierta para actuar en casos futuros muy específicos. Desde 1993, el Consejo de Seguridad se ha vuelto mucho más activo en el campo de la promoción de la democracia. El Consejo de Seguridad progresivamente vincula cada vez más las políticas democráticas a la prevención y resolución de conflictos.

Palabras clave: democracia, derecho internacional, derecho a la democracia, intervención prodemocrática; restauración de la democracia, Consejo de Seguridad de las Naciones Unidas, Haití.

ABSTRACT: This article examines whether the international community's attitude towards the promotion of democracy has altered since the military intervention in Haiti which took place almost twenty years ago. The article concludes that it partly has. The international community, acting through the Security Council, still generally opposes the idea that military force can legitimately be used to "restore" democracy, however leaving the door open to act in future very specific cases. Since 1993 the Security Council has become much more active in the field of democracy promotion. The Security Council increasingly links democratic policies to conflict prevention and conflict resolution.

Descriptors: Democracy, international law, democratic entitlement, pro-democratic intervention, restoration of democracy, United Nations Security Council, Haiti.

RÉSUMÉ: Cet article examine si l'attitude de la communauté internationale vis-à-vis la promotion de la démocratie a changé depuis l'intervention militaire en Haïti qui a eu lieu il y a presque vingt ans. L'article conclut qu'il a changé partiellement. La communauté internationale, agissant par le Conseil de sécurité, s'oppose encore à l'idée que la force militaire peut légitimement être employée pour reconstituer la démocratie, toutefois laissant la porte ouverte pour des circonstances spéciales. Puisque 1993 le Conseil de Sécurité est devenus beaucoup plus actif dans le domaine de la promotion de démocratie. Par exemple le Conseil de sécurité lie de plus en plus des politiques démocratiques à la prévention des conflits et à la résolution des conflits.

Mots-clés: La démocratie, le droit international, le principe de la démocratie en droit international, interventions pro-démocratiques, Le Conseil de Sécurité de la Nations-Unies, Haiti. 


\section{INTRODUCTION}

Democracy in international law is a recent phenomenon. It was only after the Cold War, that international law dared to address the issue of democracy which previously was considered to be a "domestic" issue and thus one not subject to international scrutiny. ${ }^{1}$ An example of this Cold War neutrality is written down in article IV Section 10 of "The Bank and its officers shall not interfere in the political affairs of any member; nor shall they be influenced in their decisions by the political character of the member or members concerned". ${ }^{2}$ In the literature this "shift in attitude" is explained by the events of 1989-1991 which led to the embrace of democracy in many countries, primarily in Eastern Europe. The "Third Wave of Democratization”, to use Samuel Huntington's term, ${ }^{3}$ led many scholars to think about the idea of democracy as a legal principle or, as Thomas Franck puts it, the "right to democratic governance".

The theory of the democratic entitlement has its roots in the eighties ${ }^{4}$ but gained fame internationally through a seminal series of articles ${ }^{5}$ of which "The Emerging Right to Democratic Governance" written by the late Professor Thomas Franck is the most famous. In that series of articles professor Franck argues that before the Cold War ended a government could only be legitimized through the will of its population. ${ }^{6}$ Due to the mentality change generated by the end of the Cold War the legi-

1 Wouters, Jan y De Meester Bart y Ryngaert Cedric, "Democracy and International Law”, N.Y.I.L., año 2003, núm. 1, p. 137.

2 The International Bank for Reconstruction and Development Articles of Agreement, http: / / web.worldbank.org/WBSITE / EXTERNAL / EXTABOUTUS/0, contentMDK:20049557 men uPK:63000601 pagePK:34542 piPK:36600 theSitePK:29708,00.html.

3 Huntington Samuel, The ThirdWave : Democratization in the Late Twentieth Century, Norman: University of Oklahoma Press, 1993, 366 pp.

4 Steiner Henry, Political Participation as a Human Right, Harv. Hum. Rts.Y.B., año 1988, núm. 1, pp. 77-134.

5 Franck Thomas, "The Emerging Right to Democratic Governance", Am. J. Int'l L., año 1992, núm. 86, pp. 46-91; Franck Thomas, "The Democratic Entitlement”, U. Rich. L. Rev., año 1994-1995, núm. 29, pp. 1-39; Franck Thomas, "Democracy as a Human Right”, Stud. Transnat'l Legal Pol'y, año 1993, núm. 26, pp. 73-101.

6 Franck Thomas, "Democracy as a Human Right”, Stud. Transnat'l Legal Pol'y, año 1993, núm. 26, p. 75. 
timacy of all governments will be determined in the future exclusively through international rules and procedures. ${ }^{7}$ The international community will only bestow legitimacy on democracies. Whether a state is democratic or not will be determined by reference to a global standard, the content of which will be defined by the international community. ${ }^{8}$ Franck argues that a consensus is emerging on the content of that global standard, i. e. the right to self-determination, the right to free and fair elections and the freedom of speech. ${ }^{9}$

Over the years the theory of the democratic entitlement has been both supported ${ }^{10}$ and criticized. ${ }^{11}$ Similar to professor Franck, proponents of the theory defend the emergence of a democratic entitlement calling for the reinterpretation of existing international law. While some authors argue that the recognition of states is dependent upon a democratic government, ${ }^{12}$ others state that certain human rights, e.g. the right to self-determination, should be reinterpreted through the

7 Franck Thomas, "The Emerging Right to Democratic Governance”, Am. J. Int'1 L., núm. 86,1992 , p. 50 .

8 Idem, p. 51.

9 Ibidem, p. 52.

10 See for instance Fox Gregory, "The Right to Political Participation in International Law”, Yale J. Int'1 L., año 1992, núm. 17, pp. 539-607; Ezetah Reginald, “The Right to Democracy: A Qualitative Inquiry”, Brook.J. Int'1 L., núm. 22, 1996-1997, pp. 495-534; Weatley Steven, "Democracy and International law: A European Perspective", Int'1 \& Comp. L. Q, año 2002, núm. 51, pp. 225-248; Udombana Nsongurua, “Articulating the right to Democratic Governance in Africa”, Mich.J. Int'1 L., núm. 24, 2002-2003, pp. 1209-1287; Cerna Christina, "Universal Democracy: An International Legal Right or the Pipe Dream of the West", N.Y.U. J. Int'1 L. \&Pol., núm. 27, 1994-1995, pp. 289-329.

11 See for instance Eckert Amy, "Free Determination or the Determination to be Free? Self-Determination and the Democratic Entitlement”, UCLA J. Int'l L. \& Foreign Affairs, núm. 4, 1999, pp. 55-79; Ebersole Jon, "National Sovereignty Revisited: Perspectives on the Emerging Norm of Democracy in International Law" (panel discussion), Am. Soc'y Int'1 L. Proc., núm. 86, 1992, pp. 249-271, Marks Susan, The Riddle of all Constitutions: International Law, Democracy and the Critique of Ideology, Oxford University Press, 2000, 164 pp.; Crawford James, Democracy and International Law, B.Y.I.L., an̆o 193, núm. 64, pp. 113-133.

12 Murphy Stephen, "Democratic Legitimacy and the Recognition of States and Governments", in Fox Gregory y Roth Brad (coord.) Democratic Governance and International Law, Cambridge University Press, 2000, pp. 123-154. 
lens of democracy. ${ }^{13}$ Many supporters of the democratic entitlement focus on the rules regarding the use of force discussing the (il)legality of pro-democratic interventions. ${ }^{14}$ Intervention is defined in this context as "dictatorial interference by a state in the affairs of another state for the purpose of maintaining or altering the actual conditions of things". ${ }^{15}$ Most authors tackling this issue address the question upon which legal basis such an intervention can be based, i.e. Security Council authorization, ${ }^{16}$ consent of the state concerned (i.e. the "legitimate government" $)^{17}$ or a treaty ${ }^{18}$ and whether such an intervention can be

13 Vandewoude Cécile, “The Rise of Self-Determination versus the Rise of Democracy", Go.J.I.L., an̆o 2010, núm. 2 (3), pp. 981-996.

14 See also the references in footnotes 16-19. Reisman W. Michael, "Coercion and Self-Determination: Construing Charter Article 2 (4)”, Am. J. Int'l L., núm. 78, 1984, pp. 642-645; Reisman W. Michael, "Humanitarian Intervention and Fledging Democracies", Fordham Int'1 L.J., núm. 18, 1994-1995, pp. 794-805; Schachter Oscar, "The Legality of Pro-Democratic Invasion”, Am.J.Int'1 L. 650, núm. 78, 1984, pp. 645-650; Gassama Ibrahim, "Safeguarding the Democratic Entitlement": A Proposal for United Nations Involvement in National Politics, Cornell Int'l L.J., núm. 30, 1997, pp. 287-333; “Donoho Douglas Lee, Evolution or Expediency: The UN Response to the Disruption of Democracy”, Cornell Int'l L.J., núm. 29, 1996, pp. 329-382; Wippman David, "Defending Democracy through Foreign Intervention”, Hous. J. Int’l L. 659, núm. 19, 1996-1997, pp. 659-687; Fielding Lois, “Taking the Next Step in the Development of New Human Rights: the Emerging Right of Humanitarian Assistance to Restore Democracy”, Duke J. Comp. \&Int’l L., núm. 5, 1994-1995, pp. 329-377; Irving Karl, "The United Nations and Democratic Intervention: Is Swords into Ballot Boxes Enough?”, Denv. J. Int'l L. \& Pol'y, núm. 25, 1996-1997, pp. 41-70.

15 Hersch Lauterpacht's definition adopted by Michael Byers and Simon Chesterman, "You, the People": pro-democratic intervention in international law", p. 260

16 Byers Michael y Chesterman Simon, "You, the People": Pro-Democratic Intervention in International law" in Fox Gregory y Roth Brad (coord.) Democratic Governance and International Law, Cambridge University Press, 2000, pp. 259-292

17 Evidently questions rise as to who constitutes the legitimate government. Wippman David, Pro-Democratic Intervention by Invitation, in Fox Gregory y Roth Brad (coord.) Democratic Governance and International Law, Cambridge University Press, 2000, pp. 293-327

18 Roth Brad, The Illegality of "Pro-Democratic" Invasion Pacts, in Fox Gregory y Roth Brad (coord.) Democratic Governance and International Law, Cambridge University Press, 2000, pp. 328-342. 
conducted solely multilaterally ${ }^{19}$ or also unilaterally. ${ }^{20}$ This present article will not address these questions but will be connected to the "use of force" aspect of the "developing international law on democracy".

In the research on democracy the case of Haiti has proven to be pivotal. First and foremost it served as a source of inspiration to Thomas Franck. ${ }^{21}$ It was also the first instance in which the Security Council explicitly authorized the use of military force to restore democracy. The facts of the Haiti case can be briefly summarized as follows. ${ }^{22}$ In September 1991, the newly-elected President Jean-Bertrand Aristide was ousted from office by a military junta headed by general Raoul Cédras and forced to flee to the United States. After Aristide's overthrow, widespread human rights abuses occurred spurring a massive flight of Haitian citizens to the United States. The Organization of American States ("OAS"), was the first to impose sanctions against the military regime. In an emergency meeting held on September 30, 1991, the OAS “recommended action to bring about the diplomatic isolation of those who hold power illegally in Haiti". ${ }^{23}$ The Permanent Council of the OAS went further and called for an economic embargo to isolate Haiti from the rest of the Western Hemisphere. ${ }^{24}$ At the urging of Western governments, the U.N. Security Council expanded the OAS embargo of Haiti to include

19 Byers Michael y Chesterman Simon, "You, the People": Pro-Democratic Intervention in International law" in Fox Gregory y Roth Brad (coord.) Democratic Governance and International Law, Cambridge University Press, 2000, pp. 259-292

20 Reisman W. Michael, Sovereignty and Human Rights in Contemporary International Law, in Fox Gregory y Roth Brad (coord.) Democratic Governance and International Law, Cambridge University Press, 2000, pp. 239-258.

21 For an in-depth discussion on the impact of the Haiti case on the reasoning of Thomas Franck see Marks Susan, "What has become of the Emerging Right to Democratic Governance?”, Eur. J. Int'l L., núm. 22, 2011, p. 519

22 Based on Nanda Ved y Muther Thomas Jr. Y Eckert Amy, “Tragedies in Somalia, Yugoslavia, Haiti, Rwanda and Liberia - Revisiting the validity of Humanitarian intervention under international law - part II", Denv. J. Int'l L. \& Pol'y, núm 26, 1997-1998, pp.842-845; Malone David, Decision-making in the UN Security Council: The Case of Haiti, 1990-1997, Oxford, Clarendon press, 1998, 322p.; Falk Richard, “The Haiti Intervention: A Dangerous World Order Precedent for the United Nations”, Harv. J. Int'l L., núm. 36, 1995, pp. 341

23 Support to the Democratic Government of Haiti, OAS Doc. MRE/RES 1/91 (October 3, 1991)

24 Id. In May, 1992, the OAS passed a second resolution after failed attempts at negotiations asking member states to renew their commitment to the embargo by denying port ac- 
all U.N. member states. ${ }^{25}$ After several diplomatic attempts to find a negotiated settlement -i.e. the Washington Accord, the Governors Island Agreement and the Malval Plan- had failed, the U.N. Security Council adopted Resolution 940, authorizing the use of "all necessary means" by a multinational coalition to restore the Aristide government in Haiti. ${ }^{26} \mathrm{At}$ the very last minute a diplomatic resolution succeeded. With the help of an American delegation including former President Jimmy Carter, Senator Sam Nunn and General Colin Powell a compromise was reached. Cédras agreed that he and the other military leaders would step down by October 15, and that American troops could enter Haiti unopposed. On September 19, U.S. troops landed peacefully in Port-au-Prince. On October 12, Cédras officially resigned, and Aristide finally returned to Haiti on October 15, 1995.

At the time of writing this article almost twenty years have passed since the intervention in Haiti and the since the establishment of the theory of the democratic entitlement. Given the occurrence of the series of uprisings in the Middle East and Africa, the UN Secretary General proclaimed the year 2011, to be a "remarkable one in the history of democracy". ${ }^{27}$ It is the purpose of this article to examine what -if any- influence the case of Haiti has had on the practice of the Security Council. Has the Security Council mandated any other pro-democratic interventions since the intervention in Haiti? Or has the theory of the democratic entitlement had any other influence on the Security Council's work? These two questions will be addressed next.

cess to ships violating the embargo, denying visa privileges to coup members, and freezing coup leaders' assets. O.A.S. Doc. OEA/Ser. G/CP/SA 896/92(8) (April 1, 1992).

25 S.C. Res. 841, U.N. SCOR, 3238 mtg. at 2, U.N. Doc. S/RES/841 (1994).

26 S.C. Res. 940, U.N. SCOR, 3413th mtg. at 2, U.N. Doc. S/RES/940 (1994).

27 Ki-Moon Ban, Secretary-General's Message on the International Day of Democracy, 2011, http://www.un.org/en/events/democracyday/sg_message_2011.shtml 


\section{HAS THE SECURITY COUNCIL AUTHORIZED ANY SANCTIONS UNDER CHAPTER VII TO RESTORE DEMOCRACY \\ SINCE THE INTERVENTION IN HAITI? ${ }^{28}$}

In the literature it is fiercely debated what elements triggered the Security Council to take action in the case of Haiti. Some authors believe the refugee flow to be the determinant element, others refer to the human rights atrocities committed, other authors refer to economic reasons..$^{29}$ The unconstitutional overthrow of a democratically elected government is generally ${ }^{30}$ considered to be one of the elements — but not sufficient in itself - to trigger Security Council action. Given the fact that the topic of this article is not whether a coup theoretically can constitute a threat to or breach of the international peace and security, this question is irrelevant here. For the purpose of this article we will just consider whether the SC has taken any action under Chapter VII in response to any other coups since Haiti.

Only in one instance has the SC endorsed the use of military force to reinstall an overthrown government, namely in the case of Sierra Leone. ${ }^{31}$ On 25 May 1997 a military coup headed by Major Johnny Paul Koromah, deposed Sierra Leone's first elected president Ahmad Tejan Kabbah. Both the UN and the African Union issued statements condemning the coup, calling for reinstatement of the democratically elected government and demanding the restoration of constitutional order. In July 1997 the Economic Organization of West African States (ECOWAS) imposed a complete embargo on Sierra Leone. In October the SC reinforced this embargo and demanded that the military junta take immediate steps to relinquish power in Sierra Leone and make way

28 Any other uses of military force (such as non-authorized humanitarian interventions) are excluded from this article.

29 For an overview of all motivations see Malone David, Decision-making in the UN Security Council:The Case of Haiti, 1990-1997, Oxford : Clarendon press, 1998,p. 160

30 However a minority does consider the unconstitutional overthrow to be the determinant factor.

31 See Reisman W. Michael, Sovereignty and Human Rights in Contemporary International Law, in Fox Gregory y Roth Brad (coord.) Democratic Governance and International Law, Cambridge University Press, 2000, p. 253 
for the restoration of the democratically elected government. The international pressure compelled Koromah to negotiate a peace agreement. His breach of the October 1997 cease fire led to military intervention. On 13 February, 1998 Nigerian troops authorized by ECOWAS displaced Koromah's military government and reinstated President Kabbah. Acting under Chapter VIII the Security Council endorsed ECOWAS' intervention.

The SC's reluctance to mandate any other pro-democratic interventions logically flows from various factors. First of all, the Security Council has adopted a case-by-case approach explicitly grounding its actions on the specific and unique circumstances of the case and as such it has been careful to avoid the creation of any kind of normative expectation and it has prevented its pro-democratic actions from crystallizing into more generally applicable legal rules. ${ }^{32}$ Secondly, military interventions are scarcely approved as the system of collective security is based on the principle of non-intervention and state sovereignty. ${ }^{33}$ Moreover the SC has various tools at its disposition, the use of force being a means of last resort. There are also several practical concerns such as the large number of nations considered to be non-democratic within the UN making it practically impossible for the international community to take action against all these nations. Other practical concerns include "mission creep", ${ }^{34}$ operational fatigue ${ }^{35}$ and financial and institutional constrains. ${ }^{36}$ Another important reason justifying the international community's reluctance is the fear for abuse. Many nations fear that democracy will used as an excuse to unlawfully interfere within

32 Gallagher Anne, The United Nations, Democracy and Human Rights, in NORDEM Manual on Human Rights Monitoring, Ingvild Burkey Siri Skåre, Hege Mørk (coop.), 2008, http: / / works.bepress.com / anne_gallagher/ 7

33 See article 2 (4) UN Charter.

34 "Mission creep" signifies that all contingencies, such as commitment of forces, time and effort, of an operation can never fully be anticipated.

35 As seen now for example in Afghanistan http://www.680news.com/news/world/ article / 251129 --cmdr-australian-special-forces-show-signs-of-fatigue-in-afghanistan-but-remaineager-to-fight

36 http://www.nytimes.com/2009/03/01/weekinreview/01glanz.html; http://hutchison.senate.gov $/ ?$ p $=$ press_release\&id $=614$ 
their domestic jurisdiction. ${ }^{37}$ In addition as Brad Roth precisely states, "all sides of a political struggle claim the democratic high ground and the multifaceted nature of the concept allows each side to make a superficially plausible case". ${ }^{38}$

There is no indication that over the past twenty years the SC has overturned or nuanced its opinion on pro-democratic interventions. Evidently, nothing precludes the SC to authorize another democratic intervention should similar exceptional circumstances occur. The question that will be addressed next is whether regardless of the status quo with regard to pro-democratic interventions, any evolution has occurred in the SC's attitude toward democracy.

\section{HAS HAD THE THEORY OF THE DEMOCRATIC ENTITLEMENT ANY OTHER INFLUENCE ON THE SECURITY COUNCIL'S WORK? ${ }^{39}$}

As stated above, democracy in international law is a recent phenomenon. This is visible within the workings of the Security Council. The Security Council has not utilized the term "democracy" or an inferred term such as "democratization" once in the period 1945-1992. Security Council resolution 864, adopted in 1993, regarding the situation in Angola was the first resolution ever to contain the term "democratic". Since then, the SC has started to use the term more frequently with a significant increase the last five years. In 1993 the term was used in 8 of the 93 resolutions $(8.6 \%) ;{ }^{40}$ in 1994 in 13 of the 77 resolu-

37 For this reason several states opposed the adoption of the term "right to democracy" in the title of a resolution. Commission on Human Rights, press release, U.N. Doc. HR/ CN/99/61 (1999)

38 Roth Brad, "Popular Sovereignty: The Elusive Norm”, Am. Soc'y Int'l L. Proc., núm. 91, 1997 , p. 367.

39 Fox Gregory, "Democracy, Right to, International Protection”, 2008, www.mpepil.com

40 S.C. Res. 864, U.N. SCOR, mtg. 3277, U.N. Doc. S/RES/864 (Sept. 15, 1993); S.C. Res. 865, U.N. SCOR, mtg. 3280, U.N. Doc. S/RES/865 (Sept. 22, 1993); S.C. Res. 867, U.N. SCOR, mtg. 3282, U.N. Doc. S/RES/867 (Sept. 23, 1993); S.C. Res. 872, U.N. SCOR, mtg. 3288, U.N. Doc. S/RES/872 (Oct. 5, 1993); S.C. Res. 880, U.N. SCOR, mtg. 3303, U.N. Doc. S/RES/880 (Nov. 4, 1993); S.C. Res. 885, U.N. SCOR, mtg. 3315, U.N. 
tions $(16,9 \%) ;{ }^{41}$ in 1995 in 5 of the 66 resolutions $(7.6 \%) ;{ }^{42}$ in 1996 in 9 of the 57 resolutions $(15,8 \%) ;^{43}$ in 1997 in 3 of the 54 resolutions $(5.5 \%) ;^{44}$ in 1998 in 7 of the 83 resolutions $(8.4 \%) ;^{45}$ in 1999 in 6 of

Doc. S/RES/885 (Nov. 16, 1993); S.C. Res. 886, U.N. SCOR, mtg. 3317, U.N. Doc. S/ RES/886 (Nov. 18, 1993); S.C. Res. 890, U.N. SCOR, mtg. 3323, U.N. Doc. S/RES/890 (Dec. 15, 1993).

${ }^{41}$ S.C. Res. 894, U.N. SCOR, mtg. 3329, U.N. Doc. S/RES/894 (Jan. 14, 1994); S.C. Res. 897, U.N. SCOR, mtg. 3334, U.N. Doc. S/RES/ 897 (Feb. 4, 1994); S.C. Res. 903, U.N. SCOR, mtg. 3350, U.N. Doc. S/RES/903 (Mar. 16, 1994); S.C. Res. 917, U.N. SCOR, mtg. 3376, U.N. Doc. S/RES/917 (May 6, 1994); S.C. Res. 919, U.N. SCOR, mtg. 3379, U.N. Doc. S/RES/919 (May 26, , 1994); S.C. Res. 930, U.N. SCOR, mtg. 3393, U.N. Doc. S/ RES/930 (Jun. 27, 1994); S.C. Res. 932, U.N. SCOR, mtg. 3395, U.N. Doc. S/RES/932 (Jun. 30, 1994); S.C. Res. 933, U.N. SCOR, mtg. 3397, U.N. Doc. S/RES/933 (Jun. 30, 1994); S.C. Res. 940, U.N. SCOR, mtg. 3413, U.N. Doc. S/RES/940 (Jul. 31, 1994); S.C. Res. 948, U.N. SCOR, mtg. 3437, U.N. Doc. S/RES/948 (Oct. 15, 1994); S.C. Res. 957, U.N. SCOR, mtg. 3458, U.N. Doc. S/RES/957 (Nov. 15, 1994); S.C. Res. 960, U.N. SCOR, mtg. 3464, U.N. Doc. S/RES/960 (Nov. 21, 1994); S.C. Res. 968, U.N. SCOR, mtg. 3482, U.N. Doc. S/RES/968 (Dec. 16, 1994).

42 S.C. Res. 991, U.N. SCOR, mtg. 3528, U.N. Doc. S/RES/991 (Apr. 28, 1995); S.C. Res. 999, U.N. SCOR, mtg. 3544, U.N. Doc. S/RES/999 (Jun. 16, 1995); S.C. Res. 1007, U.N. SCOR, mtg. 3559 U.N. Doc. S/RES/1007 (Jul. 31, 1995); S.C. Res. 1020, U.N. SCOR, mtg. 3592, U.N. Doc. S/RES/1020 (Nov. 10, 1995); S.C. Res. 1030, U.N. SCOR, mtg. 3606, U.N. Doc. S/RES/1030 (Dec. 14, 1995).

43 S.C. Res. 1040, U.N. SCOR, mtg. 3623, U.N. Doc. S/RES/1040 (Jan. 29, 1996); S.C. Res. 1048, U.N. SCOR, mtg. 3638, U.N. Doc. S/RES/1048 (Feb. 29, 1996); S.C. Res. 1061, U.N. SCOR, mtg. 3673, U.N. Doc. S/RES/1061 (Jun. 14, 1996); S.C. Res. 1063, U.N. SCOR, mtg. 3676, U.N. Doc. S/RES/1063 (Jun. 28, 1996); S.C. Res. 1072, U.N. SCOR, mtg. 3695, U.N. Doc. S/RES/1072 (Aug. 30, 1996); S.C. Res. 1086, U.N. SCOR, mtg. 3721, U.N. Doc. S/RES/1086 (Dec. 5, 1996); S.C. Res. 1087, U.N. SCOR, mtg. 3722, U.N. Doc. S/RES/1087 (Dec. 11, 1996); S.C. Res. 1088, U.N. SCOR, mtg. 3723, U.N. Doc. S/RES/1088 (Dec. 12, 1996); S.C. Res. 1089, U.N. SCOR, mtg. 3724, U.N. Doc. S/ RES/1089 (Dec. 13, 1996).

44 S.C. Res. 1132, U.N. SCOR, mtg. 3822, U.N. Doc. S/RES/1132 (Oct. 8, 1997); S.C. Res. 1141, U.N. SCOR, mtg. 3837, U.N. Doc. S/RES/1141 (Nov. 28, 1997); S.C. Res. 1145, U.N. SCOR, mtg. 3843, U.N. Doc. S/RES/1145 (Dec. 19, 1997).

45 S.C. Res. 1156, U.N. SCOR, mtg. 3861, U.N. Doc. S/RES/1156 (Mar. 16, 1998); S.C. Res. 1162, U.N. SCOR, mtg. 3872, U.N. Doc. S/RES/1162 (Apr. 17, 1998); S.C. Res. 1170, U.N. SCOR, mtg. 3886, U.N. Doc. S/RES/1170 (May 28, 1998); S.C. Res. 1171, U.N. SCOR, mtg. 3889, U.N. Doc. S/RES/1171 (Jun. 5, 1998); S.C. Res. 1181, U.N. SCOR, mtg. 3902, U.N. Doc. S/RES/1181 (Jul. 13, 1998); S.C. Res. 1201, U.N. SCOR, mtg. 3935, U.N. Doc. S/RES/1201 (Oct. 15, 1998); S.C. Res. 1212, U.N. SCOR, mtg. 3949, U.N. Doc. S/ RES/1212 (Nov. 25, 1998). 
the 65 resolutions $(9.2 \%) ;^{46}$ in 2000 in 4 of the 50 resolutions $(8 \%) ;^{47}$ in 2001 in 5 of the 52 resolutions $(9.6 \%) ;{ }^{48}$ in 2002 in 4 of the 69 resolutions $(5.8 \%) ;^{49}$ in 2003 in 7 of the 68 resolutions $(10.3 \%) ;{ }^{50}$ in 2004 in 9 of the 59 resolutions $(15.3 \%) ;{ }^{51}$ in 2005 in 11 of the 71 resolutions

46 S.C. Res. 1234, U.N. SCOR, mtg. 3993, U.N. Doc. S/RES/1234 (Apr. 9, 1999); S.C. Res. 1240, U.N. SCOR, mtg. 4004, U.N. Doc. S/RES/1240 (May 15, 1999); S.C. Res. 1244, U.N. SCOR, mtg. 4011, U.N. Doc. S/RES/1244 (Jun. 10, 1999); S.C. Res. 1265, U.N. SCOR, mtg. 4046, U.N. Doc. S/RES/1265 (Sept. 17, 1999); S.C. Res. 1272, U.N. SCOR, mtg. 4057, U.N. Doc. S/RES/1272 (Oct. 25, 1999); S.C. Res. 1274, U.N. SCOR, mtg. 4064, U.N. Doc. S/RES/1274 (Nov. 12, 1999).

47 S.C. Res. 1289, U.N. SCOR, mtg. 4099, U.N. Doc. S/RES/1289 (Feb. 7, 2000); S.C. Res. 1291, U.N. SCOR, mtg. 4104, U.N. Doc. S/RES/1291 (Feb. 24, 2000); S.C. Res. 1304, U.N. SCOR, mtg. 4159, U.N. Doc. S/RES/1304 (Jun. 16, 2000); S.C. Res. 1327, U.N. SCOR, mtg. 4220, U.N. Doc. S/RES/1327 (Nov. 13, 2000).

48 S.C. Res. 1335, U.N. SCOR, mtg. 4256, U.N. Doc. S/RES/1335 (Jan. 12, 2001); S.C. Res. 1341, U.N. SCOR, mtg. 4282, U.N. Doc. S/RES/1341 (Feb. 22, 2001); S.C. Res. 1345, U.N. SCOR, mtg. 4301, U.N. Doc. S/RES/1345 (Mar. 21, 2001); S.C. Res. 1355, U.N. SCOR, mtg. 4329, U.N. Doc. S/RES/1355 (Jun. 15, 2001); S.C. Res. 1371, U.N. SCOR, mtg.4381, U.N. Doc. S/RES/1371 (Sept. 26, 2001).

49 S.C. Res. 1410, U.N. SCOR, mtg. 4534, U.N. Doc. S/RES/1410 (May 17, 2002); S.C. Res. 1423, U.N. SCOR, mtg. 4573, U.N. Doc. S/RES/1423 (Jul. 12, 2002); S.C. Res. 1432, U.N. SCOR, mtg. 4603, U.N. Doc. S/RES/1432 (Aug. 15, 2002); S.C. Res. 1453, U.N. SCOR, mtg. 4682, U.N. Doc. S/RES/1453 (Dec. 24, 2002).

50 S.C. Res. 1457, U.N. SCOR, mtg. 4691, U.N. Doc. S/RES/1457 (Jan. 24, 2003); S.C. Res. 1471, U.N. SCOR, mtg. 4730, U.N. Doc. S/RES/1471 (Mar. 28, 2003); S.C. Res. 1480, U.N. SCOR, mtg. 4758, U.N. Doc. S/RES/1480 (May 19, 2003); S.C. Res. 1493, U.N. SCOR, mtg. 4797, U.N. Doc. S/RES/1493 (Jul. 28, 2003); S.C. Res. 1509, U.N. SCOR, mtg. 4830, U.N. Doc. S/RES/1509 (Sept. 19, 2003); S.C. Res. 1511, U.N. SCOR, mtg. 4844, U.N. Doc. S/RES/ 1511 (Oct. 16, 2003); S.C. Res. 1521 U.N. SCOR, mtg. 4890, U.N. Doc. S/RES/1521 (Dec. 22, 2003).

51 S.C. Res. 1529, U.N. SCOR, mtg. 4919, U.N. Doc. S/RES/1529 (Feb. 29, 2004); S.C. Res. 1532, U.N. SCOR, mtg. 4925, U.N. Doc. S/RES/1532 (Mar. 12, 2004); S.C. Res. 1536, U.N. SCOR, mtg. 4937, U.N. Doc. S/RES/1536 (Mar. 26, 2004); S.C. Res. 1542, U.N. SCOR, mtg. 4961, U.N. Doc. S/RES/1542 (Apr. 30, 2004); S.C. Res. 1545, U.N. SCOR, mtg. 4875, U.N. Doc. S/RES/1545 (May 21, 2004); S.C. Res. 1546, U.N. SCOR, mtg. 4987, U.N. Doc. S/RES/ 1546 (Jun. 8, 2004); S.C. Res. 1565, U.N. SCOR, mtg. 5048, U.N. Doc. S/RES/ 1565 (Oct. 1, 2004); S.C. Res. 1573, U.N. SCOR, mtg. 5079, U.N. Doc. S/RES/1573 (Nov. 16, 2004); S.C. Res. 1576, U.N. SCOR, mtg. 5090, U.N. Doc. S/ RES/1576 (Nov. 29, 2004). 
52 S.C. Res. 1589, U.N. SCOR, mtg. 5148, U.N. Doc. S/RES/1589 (Mar. 24, 2005); S.C. Res. 1590, U.N. SCOR, mtg. 5151, U.N. Doc. S/RES/1590 (Mar. 24, 2005); S.C. Res. 1599, U.N. SCOR, mtg. 5171, U.N. Doc. S/RES/1599 (Apr. 28, 2005); S.C. Res. 1608, U.N. SCOR, mtg. 5210, U.N. Doc. S/RES/1608 (Jun. 22, 2005); S.C. Res. 1618, U.N. SCOR, mtg. 5246, U.N. Doc. S/RES/1618 (Aug. 4, 2005); S.C. Res. 1623, U.N. SCOR, mtg. 5260, U.N. Doc. S/RES/1623 (Sept. 13, 2005); S.C. Res. 1625, U.N. SCOR, mtg. 5261, U.N. Doc. S/RES/1625 (Sept. 14, 2005); S.C. Res. 1626, U.N. SCOR, mtg. 5263, U.N. Doc. S/RES/1626 (Sept. 19, 2005); S.C. Res. 1637, U.N. SCOR, mtg. 5300, U.N. Doc. S/RES/1637 (Nov. 11, 2005); S.C. Res. 1639, U.N. SCOR, mtg. 5307, U.N. Doc. S/ RES/ 1639 (Nov. 21, 2005); S.C. Res. 1650, U.N. SCOR, mtg. 5341, U.N. Doc. S/RES/ 1650 (Dec. 21, 2005).

53 S.C. Res. 1653, U.N. SCOR, mtg. 5359, U.N. Doc. S/RES/1653 (Jan. 27, 2006); S.C. Res. 1658, U.N. SCOR, mtg. 5372, U.N. Doc. S/RES/1658 (Feb. 14, 2006); S.C. Res. 1659, U.N. SCOR, mtg. 5374, U.N. Doc. S/RES/1659 (Feb. 15, 2006); S.C. Res. 1662, U.N. SCOR, mtg. 5393, U.N. Doc. S/RES/1662 (Mar. 23, 2006); S.C. Res. 1669, U.N. SCOR, mtg. 5408, U.N. Doc. S/RES/1669 (Apr. 10, 2006); S.C. Res. 1674, U.N. SCOR, mtg. 5430, U.N. Doc. S/RES/1674 (Apr. 28, 2006); S.C. Res. 1683, U.N. SCOR, mtg. 5454, U.N. Doc. S/RES/1683 (Jun. 13, 2006); S.C. Res. 1690, U.N. SCOR, mtg. 5469, U.N. Doc. S/ RES/ 1690 (Jun. 20, 2006); S.C. Res. 1692, U.N. SCOR, mtg. 5479, U.N. Doc. S/RES/ 1692 (Jun. 30, 2006); S.C. Res. 1702, U.N. SCOR, mtg. 5513, U.N. Doc. S/RES/1702 (Aug. 15, 2006); S.C. Res. 1704, U.N. SCOR, mtg. 5516, U.N. Doc. S/RES/1704 (Aug. 25, 2006); S.C. Res. 1706, U.N. SCOR, mtg. 5519, U.N. Doc. S/RES/1706 (Aug. 31, 2006); S.C. Res. 1711, U.N. SCOR, mtg. 5541, U.N. Doc. S/RES/1711 (Sept. 29, 2006); S.C. Res. 1719, U.N. SCOR, mtg. 5554, U.N. Doc. S/RES/1719 (Oct. 25, 2006); S.C. Res. 1722, U.N. SCOR, mtg. 5567, U.N. Doc. S/RES/1722 (Nov. 21, 2006); S.C. Res. 1723, U.N. SCOR, mtg. 5574, U.N. Doc. S/RES/1723 (Nov. 28, 2006); S.C. Res. 1734, U.N. SCOR, mtg. 5608, U.N. Doc. S/RES/1734 (Dec. 22, 2006); S.C. Res. 1738, U.N. SCOR, mtg. 5613, U.N. Doc. S/RES/1738 (Dec. 23, 2006).

54 S.C. Res. 1740, U.N. SCOR, mtg. 5622, U.N. Doc. S/RES/1740 (Jan. 23, 2007); S.C. Res. 1743, U.N. SCOR, mtg. 5631, U.N. Doc. S/RES/1743 (Feb. 15, 2007); S.C. Res. 1744, U.N. SCOR, mtg. 5633, U.N. Doc. S/RES/1744 (Feb. 21, 2007); S.C. Res. 1745, U.N. SCOR, mtg. 5634, U.N. Doc. S/RES/1745 (Feb. 22, 2007); S.C. Res. 1746, U.N. SCOR, mtg. 5645, U.N. Doc. S/RES/1746 (Mar. 23, 2007); S.C. Res. 1756, U.N. SCOR, mtg. 5674, U.N. Doc. S/RES/1756 (May 15, 2007); S.C. Res. 1762, U.N. SCOR, mtg. 5710, U.N. Doc. S/RES/1762 (Jun. 29, 2007); S.C. Res. 1770, U.N. SCOR, mtg. 5729, U.N. Doc. S/RES/1770 (Aug. 10, 2007); S.C. Res. 1771, U.N. SCOR, mtg. 5730, U.N. Doc. S/ RES/1771 (Aug. 10, 2007); S.C. Res. 1772, U.N. SCOR, mtg. 5732, U.N. Doc. S/RES/1772 (Aug. 20, 2007); S.C. Res. 1778, U.N. SCOR, mtg. 5748, U.N. Doc. S/RES/1778 (Sept. 25, 2007); S.C. Res. 1780, U.N. SCOR, mtg. 5758, U.N. Doc. S/RES/1780 (Oct. 15, 2007); S.C. Res. 1785, U.N. SCOR, mtg. 5782, U.N. Doc. S/RES/1785 (Nov. 21, 2007); S.C. Res. 1790, U.N. SCOR, mtg. 5808, U.N. Doc. S/RES/1790 (Dec. 18, 2007); S.C. Res. 1791, 
$(24,6 \%) ;{ }^{55}$ in 2009 in 14 of the 48 resolutions $(29,2 \%)^{56}$ and in 2010 in 13 of the 59 resolutions $(22 \%) .{ }^{57}$

U.N. SCOR, mtg. 5809, U.N. Doc. S/RES/1791 (Dec. 19, 2007); S.C. Res. 1793, U.N. SCOR, mtg. 5813, U.N. Doc. S/RES/1793 (Dec. 31, 2007); S.C. Res. 1794, U.N. SCOR, mtg. 5814, U.N. Doc. S/RES/1794 (Dec. 21, 2007).

55 S.C. Res. 1796, U.N. SCOR, mtg. 5825, U.N. Doc. S/RES/1796 (Jan. 23, 2008); S.C. Res. 1801, U.N. SCOR, mtg. 5842, U.N. Doc. S/RES/1801 (Feb. 20, 2008); S.C. Res. 1802, U.N. SCOR, mtg. 5844, U.N. Doc. S/RES/1802 (Feb. 25, 2008); S.C. Res. 1806, U.N. SCOR, mtg. 5857, U.N. Doc. S/RES/1806 (Mar. 20, 2008); S.C. Res. 1814, U.N. SCOR, mtg. 5893, U.N. Doc. S/RES/1814 (May 15, 2008); S.C. Res. 1817, U.N. SCOR, mtg. 5907, U.N. Doc. S/RES/1817 (Jun. 11, 2008); S.C. Res. 1825, U.N. SCOR, mtg. 5941, U.N. Doc. S/RES/1825 (Jul. 23, 2008); S.C. Res. 1829, U.N. SCOR, mtg. 5948, U.N. Doc. S/ RES/1829 (Aug. 4, 2008); S.C. Res. 1830, U.N. SCOR, mtg. 5950, U.N. Doc. S/RES/1830 (Aug. 7, 2008); S.C. Res. 1834, U.N. SCOR, mtg. 5981, U.N. Doc. S/RES/1834 (Sept. 24, 2008); S.C. Res. 1840, U.N. SCOR, mtg. 5993, U.N. Doc. S/RES/1840 (Oct. 14, 2008); S.C. Res. 1845, U.N. SCOR, mtg. 6021, U.N. Doc. S/RES/1845 (Nov. 20, 2008); S.C. Res. 1850, U.N. SCOR, mtg. 6045, U.N. Doc. S/RES/1850 (Dec. 16, 2008); S.C. Res. 1856, U.N. SCOR, mtg. 6055, U.N. Doc. S/RES/1856 (Dec. 22, 2008); S.C. Res. 1858, U.N. SCOR, mtg. 6057, U.N. Doc. S/RES/1858 (Dec. 22, 2008); S.C. Res. 1859, U.N. SCOR, mtg. 6059, U.N. Doc. S/RES/1859 (Dec. 22, 2008).

56 S.C. Res. 1860, U.N. SCOR, mtg. 6063, U.N. Doc. S/RES/1860 (Jan. 8, 2009); S.C. Res. 1861, U.N. SCOR, mtg. 6064, U.N. Doc. S/RES/1861 (Jan. 14, 2009); S.C. Res. 1864, U.N. SCOR, mtg. 6074, U.N. Doc. S/RES/1864 (Jan. 23, 2009); S.C. Res. 1867, U.N. SCOR, mtg. 6086, U.N. Doc. S/RES/1867 (Feb. 26, 2009); S.C. Res. 1868, U.N. SCOR, mtg. 6098, U.N. Doc. S/RES/1868 (Mar. 23, 2009); S.C. Res. 1870, U.N. SCOR, mtg. 6116, U.N. Doc. S/RES/1870 (May 20, 2009); S.C. Res. 1876, U.N. SCOR, mtg. 6152, U.N. Doc. S/RES/1876 (Jun. 26, 2009); S.C. Res. 1879, U.N. SCOR, mtg. 6167, U.N. Doc. S/RES/1879 (Jul. 23, 2009); S.C. Res. 1883, U.N. SCOR, mtg. 6179, U.N. Doc. S/ RES/1883 (Aug. 7, 2009); S.C. Res. 1892, U.N. SCOR, mtg. 6200, U.N. Doc. S/RES/1892 (Oct. 13, 2009); S.C. Res. 1894, U.N. SCOR, mtg. 6116, U.N. Doc. S/RES/1894 (Nov. 11, 2009); S.C. Res. 1895, U.N. SCOR, mtg. 6220, U.N. Doc. S/RES/1895 (Nov. 18, 2009); S.C. Res. 1902, U.N. SCOR, mtg. 6245, U.N. Doc. S/RES/1902 (Dec. 17, 2009); S.C. Res. 1906, U.N. SCOR, mtg. 6253, U.N. Doc. S/RES/1906 (Dec. 23, 2009).

57 S.C. Res. 1909, U.N. SCOR, mtg. 6262, U.N. Doc. S/RES/1909 (Jan. 21, 2010); S.C. Res. 1912, U.N. SCOR, mtg. 6278, U.N. Doc. S/RES/1912 (Feb. 26, 2010); S.C. Res. 1917, U.N. SCOR, mtg. 6290, U.N. Doc. S/RES/1917 (Mar. 22, 2010); S.C. Res. 1919, U.N. SCOR, mtg. 6304, U.N. Doc. S/RES/1919 (Apr. 29, 2010); S.C. Res. 1921, U.N. SCOR, mtg. 6311, U.N. Doc. S/RES/1921 (May 12, 2010); S.C. Res. 1923, U.N. SCOR, mtg. 6321, U.N. Doc. S/RES/1923 (May 25, 2010); S.C. Res. 1925, U.N. SCOR, mtg. 6324, U.N. Doc. S/RES/1925 (May 28, 2010); S.C. Res. 1936, U.N. SCOR, mtg. 6369, U.N. Doc. S/ RES/1936 (Aug. 5, 2010); S.C. Res. 1939, U.N. SCOR, mtg. 6385, U.N. Doc. S/RES/1939 (Sept. 15, 2010); S.C. Res. 1944, U.N. SCOR, mtg. 6399, U.N. Doc. S/RES/1944 (Oct. 14, 2010); S.C. Res. 1948, U.N. SCOR, mtg. 6426, U.N. Doc. S/RES/1948 (Nov. 18, 2010); 
Over the past twenty years, the Security Council has clearly become more involved in the promotion of democracy. First of all, regardless of the SC's reluctance to militarily enforce the democratic entitlement, a consensus does appear to be emerging on the unacceptable character of any usurpations of the will of the population. The SC considers democratic governments to be synonymous with legitimate governments. ${ }^{58} \mathrm{~A}$ government can only considered to be legitimate if it based on the consent of the governed i.e. if it came to power through elections. Other means of assuming power such as the use of military activities have been explicitly condemned by the Security Council. Examples are the crisis in Burundi, where the Security Council "condemn[ed] the overthrow of the legitimate government and constitutional order in Burundi and condemn[ed] also all those parties and factions which resort to force and violence to achieve their political objectives" and "reaffirm[ed] its support for the legitimately elected institutions and stress[ed] that any attempt to seize power by force or derail the democratic process would be deemed unacceptable" ${ }^{60}$ Analogous wording was used with regard to the crisis in Sierra Leone (see above), ${ }^{61}$ Chad, ${ }^{62}$ and Côte d'Ivoire. ${ }^{63}$

The Security Council appears to accept that the credibility of the elections determines whether their outcome is accepted or not. According to the Security Council this means that elections have to be conducted in a peaceful and stable environment allowing all political parties to participate in the elections. ${ }^{64}$ The Security Council has condemned military activities directed against the elected government and

S.C. Res. 1959, U.N. SCOR, mtg. 6451, U.N. Doc. S/RES/1959 (Dec. 16, 2010); S.C. Res. 1962, U.N. SCOR, mtg. 5458, U.N. Doc. S/RES/1962 (Dec. 20, 2010).

58 See for instance S.C. Res. 1536, U.N. SCOR, mtg. 4937, U.N. Doc. S/RES/1536 (Mar. $26,2004)$, at 1.

59 S.C. Res. 1072, U.N. SCOR, mtg. 3695, U.N. Doc. S/RES/1072 (Aug. 30, 1996), at 2.

60 S.C. Res. 1719, U.N. SCOR, mtg. 5554, U.N. Doc. S/RES/1719 (Oct. 25, 2006), at 1.

61 S.C. Res. 1132, U.N. SCOR, mtg. 3822, U.N. Doc. S/RES/1132 (Oct. 8, 1997), at 2.

62 S.C. Res. 1778, U.N. SCOR, mtg. 5748, U.N. Doc. S/RES/1778 (Sept. 25, 2007), at 1; S.C. Res. 1834, U.N. SCOR, mtg. 5981, U.N. Doc. S/RES/1834 (Sept. 24, 2008), at 1; S.C. Res. 1861, U.N. SCOR, mtg. 6064, U.N. Doc. S/RES/1861 (Jan. 14, 2009), at 1.

63 S.C. Res. 1962, U.N. SCOR, mtg. 5458, U.N. Doc. S/RES/1962 (Dec. 20, 2010), at 1.

64 S.C. Res. 1734, U.N. SCOR, mtg. 5608, U.N. Doc. S/RES/1734 (Dec. 22, 2006), at 2; S.C. Res. 1917, U.N. SCOR, mtg. 6290, U.N. Doc. S/RES/1917 (Mar. 22, 2010). 
political opponents. ${ }^{65}$ In addition elections have to be transparent, ${ }^{66}$ constitutional ${ }^{67}$ and pluralistic i.e. the population has to be able to take part in the elections in great numbers. ${ }^{68}$

Secondly, the Security Council considers democracy to be a source of peace and stability both within a particular state as in the international arena. The promotion of democracy is also considered a strategy of conflict prevention which comprehensively address the root causes of armed conflict and political and social crises, to guarantee the protection of civilians on a long-term basis, and to facilitate the implementation of protection mandates. ${ }^{69}$ The Security Council seems to accepts the presumption that peace and stability flow from certain characteristics of a democratic society such as equality, non-discrimination, the idea of the consent of the governed, and the notion that disputes can be resolved peacefully because democratic institutions will secure individual rights. ${ }^{70}$ The fact that democracies possess those qualities takes away any possible grounds for conflict.

The Security Council has observed that exclusionary and discriminatory policies lie at the basis of many conflicts. Therefore the Security Council stresses the importance of unified, inclusive societies in which all members of society are equal and enjoy the same participatory rights. In addition, a democratic government has to be representative of the entire population including all racial and ethnic groups and women and children. The situations in South Africa, Bosnia Herzegovina and Iraq provide clear examples. After the abolishment of the system of Apartheid the Security Council "welcome[ed] the first all-race multiparty election and the establishment of a united, democratic, non-racial government of

65 S.C. Res. 1756, U.N. SCOR, mtg. 5674, U.N. Doc. S/RES/1756 (May 15, 2007), at 5.

66 S.C. Res. 1734, U.N. SCOR, mtg. 5608, U.N. Doc. S/RES/1734 (Dec. 22, 2006), at 2.

67 S.C. Res. 1511, U.N. SCOR, mtg. 4844, U.N. Doc. S/RES/1511 (Oct. 16, 2003), at 2

68 S.C. Res. 1711, U.N. SCOR, mtg. 5541, U.N. Doc. S/RES/1711 (Sept. 29, 2006), at 1.

69 S.C. Res. 1265, U.N. SCOR, mtg. 4046, U.N. Doc. S/RES/1265 (Sept. 17, 1999), at 1; S.C. Res. 1738, U.N. SCOR, mtg. 5613, U.N. Doc. S/RES/1738 (Dec. 23, 2006), at 2; S.C. Res. 1894, U.N. SCOR, mtg. 6116, U.N. Doc. S/RES/1894 (Nov. 11, 2009), at 6; S.C. Res. 1625, U.N. SCOR, mtg. 5261, U.N. Doc. S/RES/1625 (Sept. 14, 2005).

70 Valerie Epps, Peace and Democracy: The Link and Policy Implications, 4 ILSA J. Int'l \& Comp. L. 347 352-353(1998). 
South Africa" ${ }^{71}$ With regard to Bosnia Herzegovina, the Security Council "welcome[ed] the reaffirmation of the president of Bosnia Herzegovina... of its commitment to fully pursu[e], in the name of the three constituent peoples of Bosnia Herzegovina, the peace process... including the development of a Bosnian State based on the principles of democracy...". ${ }^{72}$ In later resolutions the Security Council welcomes the commitment of Bosnia Herzegovina to "mak[ing] progress towards fully meeting the standards of a modern democracy as a multi-ethnic, multicultural and united society" ${ }^{73}$ comprising "stable democratic and multi-ethnic political and administrative institutions". ${ }^{74}$ In the case of Iraq the Security Council "welcomed the commitment of the Interim Government of Iraq to work towards a federal, democratic, pluralistic and united Iraq, in which there is full respect for political and human rights... including the rights of women". ${ }^{75}$

According to the Security Council, a democratic society guarantees respect for human rights and the principles of equality and non-discrimination through concepts such as the rule of law and democratic effective institutions such as an independent and effective judiciary, a military and police force that capable of maintaining peace and security _ including maintaining the extension of the central government's authority over the entire territory $-{ }^{76}$ and is accountable to the (democratically elected) civilian government. As the presence of these principles and institutions is essential for the consolidation of democracy they are considered to be key elements in the avoidance of possible conflicts. Therefore, the Security Council occasionally has included the establishment or strengthening of democratic institutions, ${ }^{77}$ the promotion of

71 S.C. Res. 919, U.N. SCOR, mtg. 3379, U.N. Doc. S/RES/919 (May 26,1994); S.C. Res. 930, U.N. SCOR, mtg. 3393, U.N. Doc. S/RES/930 (Jun. 27, 1994).

72 S.C. Res. 1088, U.N. SCOR, mtg. 3723, U.N. Doc. S/RES/1088 (Dec. 12, 1996), at 3.

73 S.C. Res. 1423, U.N. SCOR, mtg. 4573, U.N. Doc. S/RES/1423 (Jul. 12, 2002), at 1.

74 Id. at 2

75 S.C. Res. 1546, U.N. SCOR, mtg. 4987, U.N. Doc. S/RES/1546 (Jun. 8, 2004), at 1; S.C. Res. 1637, U.N. SCOR, mtg. 5300, U.N. Doc. S/RES/1637 (Nov. 11, 2005), at 1; S.C. Res. 1723, U.N. SCOR, mtg. 5574, U.N. Doc. S/RES/1723 (Nov. 28, 2006), at 1.

76 S.C. Res. 1623, U.N. SCOR, mtg. 5260, U.N. Doc. S/RES/1623 (Sept. 13, 2005), at 1.

77 S.C. Res. 886, U.N. SCOR, mtg. 3317, U.N. Doc. S/RES/886 (Nov. 18, 1993), at 1; S.C. Res. 1272, U.N. SCOR, mtg. 4057, U.N. Doc. S/RES/1272 (Oct. 25, 1999), at 3; S.C. Res. 1599, U.N. SCOR, mtg. 5171, U.N. Doc. S/RES/1599 (Apr. 28, 2005), at 2; S.C. 
the rule of $\operatorname{law}^{78}$ and the advising of law enforcement agencies on guidelines on democratic policing principles with full support for human rights in peacekeeping mandates. ${ }^{79}$ The Security Council has welcomed on various occasions the re-establishment by governments of effective administration and the democratic process. ${ }^{80}$ In response to the crisis in Haiti, the Security Council "reaffirm[ed] the importance of a professional, self-sustaining, fully functioning national police of adequate size and structure, able to conduct the full spectrum of police functions, for the consolidation of democracy and the revitalization of Haiti's system of justice." ${ }^{81}$

The Security Council frequently links democracy to national reconciliation. ${ }^{82}$ For instance, with regard to the situation in Mozambique the Security Council "call[ed] upon all Mozambican parties to complete the process of national reconciliation based, as provided for in the General Peace Agreement, on a system of multi-party democracy and the observance of demo-

Res. 1794, U.N. SCOR, mtg. 5814, U.N. Doc. S/RES/1794 (Dec. 21, 2007), at 4; S.C. Res. 1829, U.N. SCOR, mtg. 5948, U.N. Doc. S/RES/1829 (Aug. 4, 2008), at 2.

78 S.C. Res. 1794, U.N. SCOR, mtg. 5814, U.N. Doc. S/RES/1794 (Dec. 21, 2007), at 4; S.C. Res. 1829, U.N. SCOR, mtg. 5948, U.N. Doc. S/RES/1829 (Aug. 4, 2008), at 2.

79 S.C. Res. 1088, U.N. SCOR, mtg. 3723, U.N. Doc. S/RES/1088 (Dec. 12, 1996), at 6; S.C. Res. 1181, U.N. SCOR, mtg. 3902, U.N. Doc. S/RES/1181 (Jul. 13, 1998), at 3; S.C. Res. 1509, U.N. SCOR, mtg. 4830, U.N. Doc. S/RES/1509 (Sept. 19, 2003), at 4; S.C. Res. 1545, U.N. SCOR, mtg. 4875, U.N. Doc. S/RES/1545 (May 21, 2004), at 4; S.C. Res. 1565, U.N. SCOR, mtg. 5048, U.N. Doc. S/RES/1565 (Oct. 1, 2004), at 4; S.C. Res. 1590, U.N. SCOR, mtg. 5151, U.N. Doc. S/RES/1590 (Mar. 24, 2005), at 4; S.C. Res. 1706, U.N. SCOR, mtg. 5519, U.N. Doc. S/RES/1706 (Aug. 31, 2006), at 4.

80 S.C. Res. 1171, U.N. SCOR, mtg. 3889, U.N. Doc. S/RES/1171 (Jun. 5, 1998), at 1; S.C. Res. 1181, U.N. SCOR, mtg. 3902, U.N. Doc. S/RES/1181 (Jul. 13, 1998), at 1

81 S.C. Res. 1212, U.N. SCOR, mtg. 3949, U.N. Doc. S/RES/1212 (Nov. 25, 1998), at 2.

82 More examples that the ones cited in text are S.C. Res. 1040, U.N. SCOR, mtg. 3623, U.N. Doc. S/RES/1040 (Jan. 29, 1996), at 2; S.C. Res. 1171, U.N. SCOR, mtg. 3889, U.N. Doc. S/RES/1171 (Jun. 5, 1998), at 1; S.C. Res. 1181, U.N. SCOR, mtg. 3902, U.N. Doc. S/RES/1181 (Jul. 13, 1998), at 1; S.C. Res. 1201, U.N. SCOR, mtg. 3935, U.N. Doc. S/ RES/1201 (Oct. 15, 1998), at 2; S.C. Res. 1432, U.N. SCOR, mtg. 4603, U.N. Doc. S/ RES/1432 (Aug. 15, 2002), at 1; S.C. Res. 1840, U.N. SCOR, mtg. 5993, U.N. Doc. S/ RES/ 1840 (Oct. 14, 2008); S.C. Res. 1867, U.N. SCOR, mtg. 6086, U.N. Doc. S/RES/1867 (Feb. 26, 2009), at 2; S.C. Res. 1870, U.N. SCOR, mtg. 6116, U.N. Doc. S/RES/1870 (May 20, 2009), at 2; S.C. Res. 1892, U.N. SCOR, mtg. 6200, U.N. Doc. S/RES/1892 (Oct. 13, 2009), at 1; S.C. Res. 1902, U.N. SCOR, mtg. 6245, U.N. Doc. S/RES/1902 (Dec. 17, 2009), at 3. 
cratic principles which will ensure lasting peace and political stability." ${ }^{33}$ With regard to the crisis in Tajikistan, the Security Council stated that "the international assistance provided by this resolution must be linked to the process of national reconciliation and the promotion of democracy". ${ }^{84}$ In the following paragraph the Security Council "recall[ed] the commitments made by the Tajik parties to resolve the conflict and to achieve national reconciliation in the country exclusively through peaceful, political means on the basis of mutual concessions and compromises...". ${ }^{85}$ The Security Council has also "reject[ed] the use of violence in in pursuit of political aims and stresses that only peaceful political solutions can assure a stable and democratic future. ${ }^{86}$ Regarding the crisis in Iraq the Security Council "encourage[ed] the Government of Iraq to engage to engage with all those who renounce violence and to promote a political atmosphere conducive to national reconciliation and political competition through peaceful, democratic means." ${ }^{87}$ Moreover, the Security Council has included the promotion of national reconciliation and democracy in peacekeeping mandates, for instance in the case of Tajikistan ${ }^{88}$ and Timor-Leste. ${ }^{89}$

The Security Council has also confirmed at various occasions that democracy contributes to stability in the inter-state relations. For instance in the case of Burundi the Security Council supported the African Union's efforts “aimed at returning Burundi to a democratic path and contributing to stability in the region." ${ }^{\circ}$ Similarly, the Security Council "call[ed] upon the international community... to support the Iraqi people in their pursuit of peace, stability, security and democracy... and not[ed] the con-

83 S.C. Res. 957, U.N. SCOR, mtg. 3458, U.N. Doc. S/RES/957 (Nov. 15, 1994), at 1.

${ }^{84}$ S.C. Res. 1030, U.N. SCOR, mtg. 3606, U.N. Doc. S/RES/1030 (Dec. 14, 1995), at 1. 85 Id.

86 S.C. Res. 1371, U.N. SCOR, mtg.4381, U.N. Doc. S/RES/1371 (Sept. 26, 2001), at 1.

87 S.C. Res. 1637, U.N. SCOR, mtg. 5300, U.N. Doc. S/RES/1637 (Nov. 11, 2005), at 2.

88 For instance in Tajikistan S.C. Res. 968, U.N. SCOR, mtg. 3482, U.N. Doc. S/RES/968 (Dec. 16, 1994), at 2; S.C. Res. 1030, U.N. SCOR, mtg. 3606, U.N. Doc. S/RES/1030 (Dec. 14, 1995), at 2; S.C. Res. 1089, U.N. SCOR, mtg. 3724, U.N. Doc. S/RES/1089 (Dec. 13, 1996), at 2 .

89 S.C. Res. 1704, U.N. SCOR, mtg. 5516, U.N. Doc. S/RES/1704 (Aug. 25, 2006), at 3.

90 S.C. Res. 1072, U.N. SCOR, mtg. 3695, U.N. Doc. S/RES/1072 (Aug. 30, 1996), at 2. 
tribution that the successful implementation of this resolution will bring to regional stability". ${ }^{91}$

\section{CONCLUSION}

Before the Security Council authorized the intervention in Haiti, the international community opposed the idea that military force could be used to "restore" democracy. The intervention in Hait has proven to be a sui generis case as twenty years later the Security Council has not deviated from its general reluctance to authorize the use of all necessary means to restore democracy. In only one instance, namely in the case of Sierra Leone has the Security Council been willing to endorse the action undertaken by ECOWAS. However, this status quo should not be interpreted as a status quo on the issue of democracy. In 1993 the SC started to deal with the issue of democracy. The SC increasingly links democratic policies to conflict prevention and conflict resolution. Democratic policies are seen as an essential counter to the exclusionary policies thought to have precipitated many conflicts. As part of its reconstruction activities in post-conflict situations the promotion of democracy been included in peacekeeping mandates. Over the past twenty years significant progress has been made with regard to the democratic entitlement. The community appears to be more committed and willing to pursue certain activities to promote democracy. Its remains however very clear that these activities can only be done in compliance with the United Nations Charter.

91 S.C. Res. 1637, U.N. SCOR, mtg. 5300, U.N. Doc. S/RES/1637 (Nov. 11, 2005), at 1. 